\title{
Monitoring and Statistical Evaluation of Heavy Metals in Respirable Dust in Jos Metropolitan Area, Nigeria
}

\author{
G. M. Mafuyai, ${ }^{* 1}$ J. J. Gongden ${ }^{1}$ and N. M. Kamoh ${ }^{2}$ \\ 1. Department of Chemistry university of Jos, Nigeria \\ 2. Department of Mathematics and Statistics Bingham University, Nigeria.
}

\begin{abstract}
The concentration of heavy metals in respiration dust $(<10 \mu \mathrm{g})$ within Jos Metropolis was monitored in seven sites made up of two industrial and high traffic areas each, with residential site as control were studied for nine consecutive months (October, 2013 to June, 2014). The concentrations of the heavy metals were studied in terms dust mass, time dependence and safety. The mass of respirable dust ranged from $0.079-0.288 \mathrm{~g}$, while the mean concentration ranged from $49-208 u g / \mathrm{m}^{3}$. Flame Atomic Absorption Spectrometry (FAAS) analysis shows that the concentrations of heavy metals ranged from $\mathrm{Pb},(0.016-0.331) \mathrm{mg} / \mathrm{kg}, \mathrm{Cr},(0.016-0.118) \mathrm{mg} / \mathrm{kg}$ $\mathrm{Fe},(0.012-0.652) \mathrm{mg} / \mathrm{kg},(0.07-0.056) \mathrm{mg} / \mathrm{kg}, \mathrm{Cd},(0.002-0.107) \mathrm{mg} / \mathrm{kg}, \mathrm{Zn},(0.0233-0.988) \mathrm{mg} / \mathrm{kg}, \mathrm{Cu}$, $(0.023-0.668) \mathrm{mg} / \mathrm{kg}$ and $\mathrm{Ni}(0.004-0,058) \mathrm{mg} / \mathrm{kg}$ across sites studied. The data obtained were treated statistically using one-way analysis of variance at $95 \%$ confidence limit for mean and correlated with the anthropological and industrial activities of the sites. The main sources of these heavy metals in the sampled areas, was attributed to anthropogenic activities like open incineration of waste, vehicular traffic and ongoing construction work within some of the sites.
\end{abstract}

Keywords: Concentration; Respirable Dust; Heavy Metals; Air Quality; Statistical Analysis

\section{Introduction}

Pollution of the natural environment by heavy metals is a worldwide problem due to the indestructible nature and toxic effects on living organism, while some of these elements are essential for humans, high levels can become toxicological risk (Shinggu, et al., 2010). About $4-8$ percent of deaths occurring annually in the world are related to air pollution associated with anthropogenic activities (Lopez, et al., 2005). Environmental sources of air pollution may include crustal mineral, forest fire, construction and demolition activities, mining and mineral processing, agricultural activities, sea spray, wind-blown dust, automobiles and transportation related activities (Maleku, et al., 2008 and Garcia, et al., 2009). The composition of the air pollutants can be inorganic, organic or a complex mixture of both. The many inorganic pollutions originating from anthropogenic activities, heavy metals are of a major concern due to their toxic and potential carcinogenic effects. In recent times, studies of air pollution especially in the urban environment have focused largely on respirable dust and seasonal variation due to threat pose to human health (Maleku, et al., 2008 and Lazor, et al., 2012].

Respirable dust pollution which gives rise to atmospheric heavy metal composed very fine dust particles which is able to reach the lower bronchioles and alveolar regions of the lung, (Kim, et al., 2002, Shah, et al., 2006, Ahmed and Ishiga 2006). Respirable dusts are useful indicators of the level and distribution of heavy metals contamination in the atmosphere (Sezgin, et al., 2006). Therefore, heavy metals in atmospheric dust can generate airborne particles which may affect air quality and also cause harm to human life and make the environment deleterious (Aybek and Selcuk, 2007). It has been reported that metals absorbed in respirable dust suspended particulate damage lungs (Pope, et al., 1995). The health effects of toxic metals in the air and from road deposited dust on human is better appreciated if one consider the fact that an active person typically inhales 10,000 to 20, 000 litres of air daily (Gbadebo and Bankole, 2007). It is logical to note that, this intake increases with vigorous exercise. During inhalation, these pollutants may enter the numerous tiny air sacs deep inside the lungs and blood stream thereby affecting several other organs than the lungs (Gbadebo and Bankole, 2007). It has been estimated that a man can live weeks without food and five days without water, but only five minutes without air (Ran and Rao. 1989). This implies that air is very essential for human existence, in view of the increasing evidences of respirable dust on human health and environment not much data on respirable dust, one of the major pre-requisite for health studies is available for urban areas in Nigeria. Information regarding respirable dust quality in Jos metropolis which is currently experiencing road construction infrastructure, high inflow of vehicular traffic, is not available. This study represents a unique combination of sampling respirable dust and its characterization. Also, it evaluates the levels of some selected heavy metals $(\mathrm{Pb}, \mathrm{Cr}, \mathrm{Fe}, \mathrm{Cd}, \mathrm{Zn}$, $\mathrm{Cu}$, and $\mathrm{Ni}$ ) in respirable dust of Jos metropolis, Nigeria. The study will form the baseline data that can be use for planning and management strategy to achieving better environmental quality and substantial development in Jos. 


\subsection{Study Area}

\section{Materials and Method}

Jos is one of the most densely populated areas in Plateau State, Nigeria (900,000 inhabitants based on the 2006 population census estimate). Jos city (latitude 956 north and Longitude 853 East) is at an elevation of about 1238 metres above sea level and host many industrial sites for steel, brewery, textile, smelting etc. It also includes power plant and experiences some of the state heaviest road traffic. It enjoys a more temperature climate than much of the rest of Nigeria. The state is characterized with landscape of undulating highlands and peaks like the famous Shere Hill over 4829 meters above sea level.

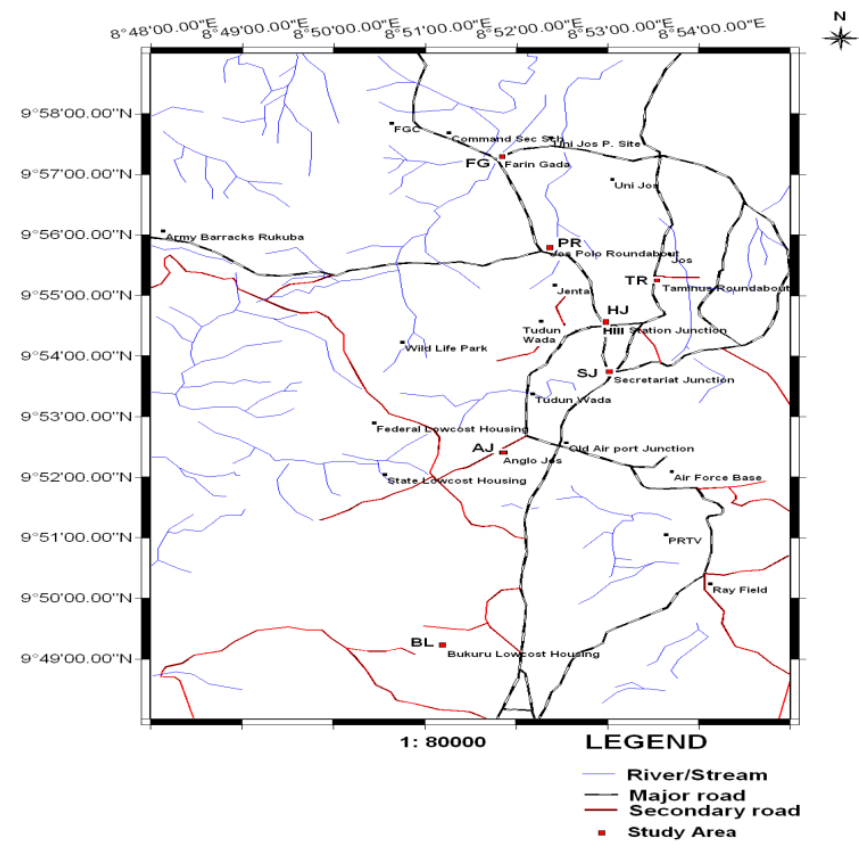

Figure 1. Map of Jos indicating the study area.

\subsection{Sampling}

The six sampling sites were carefully selected due to various activities such as industrial site, construction works and heavy traffic congested area while one other site Bukuru Low-Cost Housing Estate, a residential area, was selected as a control.

A respirable dust sampler (AAS217BL) was placed on an elevated platform of $1.5 \mathrm{~m}$ high and a distance of $20 \mathrm{~m}$ away from obstructions and used to sample the dust from Anglo Jos (AJ), Terminus Roundabout (TR), Farin-GAda (FG), Polo Roundabout (PR), Secretariat Junction (SJ), Hill Station Junction (HS), and Bukuru Low Cost Housing Estate (BL) (Fig.1). After setting the machine, marked weighed sampling bottles were fixed under the conical hopper one at a time. Marked and pre-weighted filter paper was then clamped between the top cover of filter adaptor assembling of the machine. The filter cover was then closed and the machine switched on taking note of the time. The filter papers and sample bottles were removed after 8 hours and reweighed to obtain their weight after exposure. The volume of sampled air was obtained from flowmeter reading and sampling time. Calculations were carried out using standard methods of National Environmental Engineering Research Institutes. The concentrations of the dust was obtained using the following mathematical expression:

$\mathrm{RD} \mu \mathrm{g} / \mathrm{m}^{3}=\{$
$\mathrm{RD}$

$$
\mathrm{RD} \mu \mathrm{g} / \mathrm{m}^{3}=\left\{\left(\mathrm{M}_{2}-\mathrm{M}_{1}\right) / \mathrm{V}\right\} \times 10^{6}
$$

$M_{1}$ and $M_{2}=$ initial and final mass of filter paper in grams, respectively.

$10^{6}=$ conversion factor

$\mathrm{V}=$ volume of sampled air in $\mathrm{m}^{3}$, calculated as $\mathrm{V}=\varnothing \mathrm{T}$,

$\varnothing=$ average air flow rate in $\mathrm{m}^{3} / \mathrm{min}$ and

$\mathrm{T}=$ sampling time, in minutes.

The dust collected was digested using concentrated nitric acid and filtered through Whatman filter paper number 42 and the final volume made up to $100 \mathrm{ml}$, with deionised water. A blank was also prepared in similar way as the sample. The filtrate was examined for the concentration of $\mathrm{Fe}, \mathrm{Zn}, \mathrm{Cu}, \mathrm{Pb}, \mathrm{Mn}, \mathrm{Ni}, \mathrm{Cd}, \mathrm{Cr}$, using FAAS (PG 990) in accordance with the user manual. 


\subsection{Respirable dust}

\section{Results and Discussion}

The experimental data collected in this research were analyzed statistically using tables and bar charts. The mean values of the mass of dusts in each sampling sites along with their standard deviations are presented in Table 1.

The total mass of respirable dust $(<10 \mu \mathrm{m})$ collected in Secretariat Junction (SJ) $0,254 \mathrm{~g}$ and Farin-Gada (FG) $0.288 \mathrm{~g}$ were the highest, while Hill station junction (HS) $0.148 \mathrm{~g}$ was the lowest. The messes were higher along high traffic roads and construction sites than areas with low traffic. This high value of respirable dusts may have a negative impact on the inhabitants thereby causing respiratory problems in these areas (Kim, et al., 2002).

The mass of respirable dust particles were higher in the months of December, January and February Sin most of the sampling sites, especially in Secretariat Junction and Farin-Gada. This is in line with literature reported of high value of total masses of the dust collected from Jos to be $3.3 \pm 1.1 \mathrm{~g}$ during the harmattan using smeared microscope slide for sample collection (Tsor, 2003). This high value could be due to climatic condition of harmattan as it is similar to haze where at time visibility is very poor. In addition to harmattan situation, the methods of sampling could also contribute to the high masses.

This observation was in line with literature report that, naturally derived heavy metals are usually found in respirable dust particles (Stone, et al., 2011). However, heavy metals of anthropogenic origin are mainly distributed in fine particles which are able to carry more toxic chemicals to human being and ecosystem than coarse fractions (Zhao, et al., 2011).

Table 1: Mean respirable dust mass, flow rate and volume of air sampled in Jos Metropolis between October 2013 to June 2014

\begin{tabular}{llrrr}
\hline Sample code & $\begin{array}{l}\text { Mean Mass of Dust } \\
(\mathrm{g})\end{array}$ & $\begin{array}{l}\text { Flow rate } \\
\left(\mathrm{m}^{3} / \mathrm{min}\right)\end{array}$ & $\begin{array}{l}\text { Sampling Time } \\
(\mathrm{mins})\end{array}$ & $\begin{array}{l}\text { volume of air } \\
\text { sampled }\left(\mathrm{m}^{3}\right)\end{array}$ \\
\hline AJ & $0.174 \pm 0.001$ & 0.98 & 1440 & 1441 \\
TR & $0.183 \pm 0.004$ & 0.87 & 1440 & 1253 \\
FG & $0.254 \pm 0.010$ & 0.93 & 1440 & 1339 \\
PR & $0.163 \pm 0.009$ & 0.88 & 1440 & 1267 \\
SJ & $0.288 \pm 0.020$ & 0.96 & 1440 & 1382 \\
HS & $0.148 \pm 0.007$ & 0.98 & 1440 & 1441 \\
BL & $0.079 \pm 0.040$ & 1.13 & 1440 & 1627 \\
\hline
\end{tabular}

Table 2: Monthly concentration of respirable dust $\left(\mu \mathrm{g} / \mathrm{m}^{3}\right)$ distribution at the selected areas of the study

\begin{tabular}{|c|c|c|c|c|c|c|c|}
\hline Months & AJ & $\mathrm{TR}$ & $\mathrm{FG}$ & PR & SJ & HS & $\mathrm{BL}$ \\
\hline Oct & 128 & 142 & 175 & 109 & 175 & 99 & 43 \\
\hline Nov & 137 & 128 & 194 & 126 & 176 & 92 & 40 \\
\hline Dec & 141 & 154 & 206 & 148 & 233 & 107 & 57 \\
\hline Jan & 148 & 156 & 214 & 152 & 255 & 115 & 60 \\
\hline Feb & 150 & 158 & 211 & 155 & 252 & 113 & 52 \\
\hline Mar & 147 & 149 & 208 & 148 & 251 & 120 & 59 \\
\hline Apri & 156 & 156 & 215 & 130 & 255 & 117 & 47 \\
\hline May & 113 & 130 & 149 & 102 & 145 & 85 & 40 \\
\hline Jun & 106 & 133 & 139 & 89 & 136 & 73 & 36 \\
\hline
\end{tabular}

The results shows that the dust concentration in Secretariat Junction $(255 \mu \mathrm{g} / \mathrm{m} 3)$ and Farin-Gada $\left(214 \mu \mathrm{g} / \mathrm{m}^{3}\right)$ are higher than others as shown in Table 2. This may be as a result of the construction work and heavy traffic experience in such areas.

The monthly mean concentration obtained for all the sampling stations are graphically presented in Figure 2. The mean concentration of the dust in all the sites studied is lower compared to literature value of $739.69 \mu \mathrm{g} / \mathrm{m}^{3}$ obtained at Otukpo in Benue State (Sombo, 2006) and that obtained in Cairo Egypt 396-652 $\mu \mathrm{g} / \mathrm{m}^{3}$ (USAID/Egypt, 1994). This could be attributed to geographical locations, nature of road ( tarred or untarred), the speed of vehicle and the type of fuel used (Sombo, 2006).

There has been reports on the adverse health effects ,even when respirable dust concentrations are below Ambient Standards of EPA or WHO (WHO, 1997). It is logical too that these standards ignore the synergistic effects of the concentration of toxic air pollution (Curtis, et al., 2006). respirable dust in three sub- 
urban and rural sites has also been reported to vary from $37-959 \mu \mathrm{g} / \mathrm{m}^{3}$ and $151-422 \mu \mathrm{g} / \mathrm{m}^{3}$ at sub-urban site Ronke, India (Vandana, et al., 2011). The highest concentration reported in this work is within the range of literature values reported by various workers.

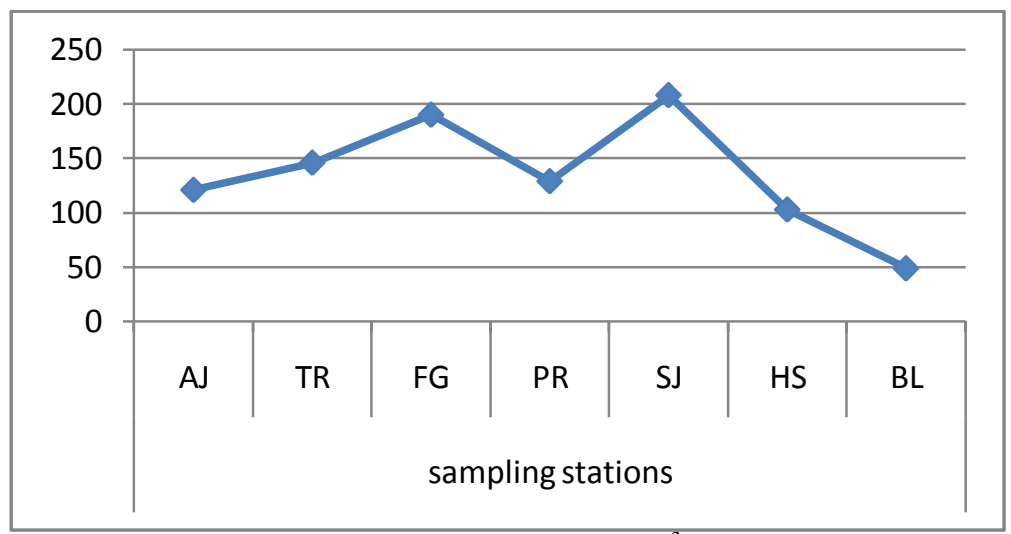

Figure 2: Mean concentration of respirable dust $\left(\mu \mathrm{g} / \mathrm{m}^{3}\right)$ distribution in Jos Metropolis

\section{Heavy Metals}

The concentration of eight $(8)$ heavy metals $(\mathrm{Pb}, \mathrm{Cr}, \mathrm{Fe}, \mathrm{Cd}, \mathrm{Zn}, \mathrm{Cu}$, and $\mathrm{Ni}$ ) at each sampling station was determined by flame atomic absorption spectrometry (FAAS) and statistically analysed one way-way analysis of variance (ANOVA). The results of determination of heavy metals in the dust fractions in seven sampling site (with control) in Jos Metropolis from October 2013 to June 2014 are presented monthly in Table 3. These results show that the analytical procedure and method of detection provided a data within acceptable range of literature values.

Lead $(\mathrm{Pb})$ naturally occurred as a bluish-grey metal found in small amount in the earth's. crust. $\mathrm{Pb}$ dust or fumed are easily absorbed by the respiratory tract, once absorbed through the respiratory tract it is distributed particularly to the liver and kidney, and is then stored in the bones. Pb affects the red blood cells and cause damage to internal organs, as well as causes effects to the immune system. Exposure to $\mathrm{Pb}$ is more dangerous young and unborn children because it leads to premature births, smaller babies, and decreased metal ability in the infant, learning difficulties, and reduced growth in young children. Lead in plumbing, solders, paints, ceramic-ware, plastics and ammunition pose a significant environment risk (Awan and Ahmed, 2011).

The concentration of $\mathrm{Pb}$ obtained in all the sampling sites was highest at Farin Gada $(0.511 \mathrm{mg} / \mathrm{kg})$ in the month of January and lowest Bukuru Low-cost $(0.004 \mathrm{mg} / \mathrm{kg})$ during the period of monitoring as depicted in Table 3. and the mean value presented in Table 4. This was found to be slightly below the annual mean $\mathrm{Pb}$ limit of $0.5 \mathrm{mg} / \mathrm{kg}$. (NEPC, 2002). This value may be associated with manufacturing of automobile batteries pigments and cable sheathing, it might also be due to wind-blown from mechanical workshops, oil linkages from cars and vehicular exhaust at the sites (U.S.EPA,2012).

Cadmium is found as a mineral combined with elements such as oxygen $(\mathrm{CdO})$, chlorine $\left(\mathrm{CdCl}_{2}\right)$ or sulphur $\mathrm{CdSO}_{4}$ or $\mathrm{CdS}$ ). It enters air from mining, industry, and burning coal and household wastes, particles of $\mathrm{Cd}$ in air can travel long distances before falling to the ground or water. The concentration of $\mathrm{Cd}$ in all the areas was higher than the standard limit value of $0.005 \mathrm{mg} / \mathrm{kg}$ as the result ranges from $0.002-0.107 \mathrm{mg} / \mathrm{kg}$. The highest value was obtained at Farin-Gada in March while the least value was obtained at Terminus roundabout Table 3. The high $\mathrm{Cd}$ in some sampling area may be associated with industrial emissions especially steel production units because a large amount of $\mathrm{Cd}$ plated steel scrap is recycled in these industries. Other possible source include burning of municipal wastes containing discarded $\mathrm{Ni}-\mathrm{Cd}$ batteries and plastics containing $\mathrm{Cd}$ pigments; vehicular emissions including tyre abrasions and cigarette smoking (Awan and Ahmed, 2011). Cd stays in the body for a very long time and hence, exposure to lower levels of Cd leads to a build up of $\mathrm{Cd}$ in the kidneys and possible kidney disease. Other potential long term effects are lung damage, fragile bones and abdominal pain (Lazor, et al., 2012).

Although, Manganese is an essential nutrient for both plants and animals but very high concentration in the respirable dust could be dangerous. The concentration of Mn determined in all the sites ranges from $0.007-$ $0.056 \mathrm{mg} / \mathrm{kg}$ during the period of assessment. The highest concentration of $\mathrm{Mn}$ was obtained at Polo roundabout in the month of January, while the least value obtained at Terminus Roundabout in the month of April (see Table 3)Although, the values obtained were lower than the WHO and EU limit value of $0.15 \mathrm{mg} / \mathrm{kg}$, bioaccumulation in the body can be deleterious to health. 
Table 3: Monthly Concentrations of heavy metals in respirable dust $(\mathrm{mg} / \mathrm{kg})$ in the study

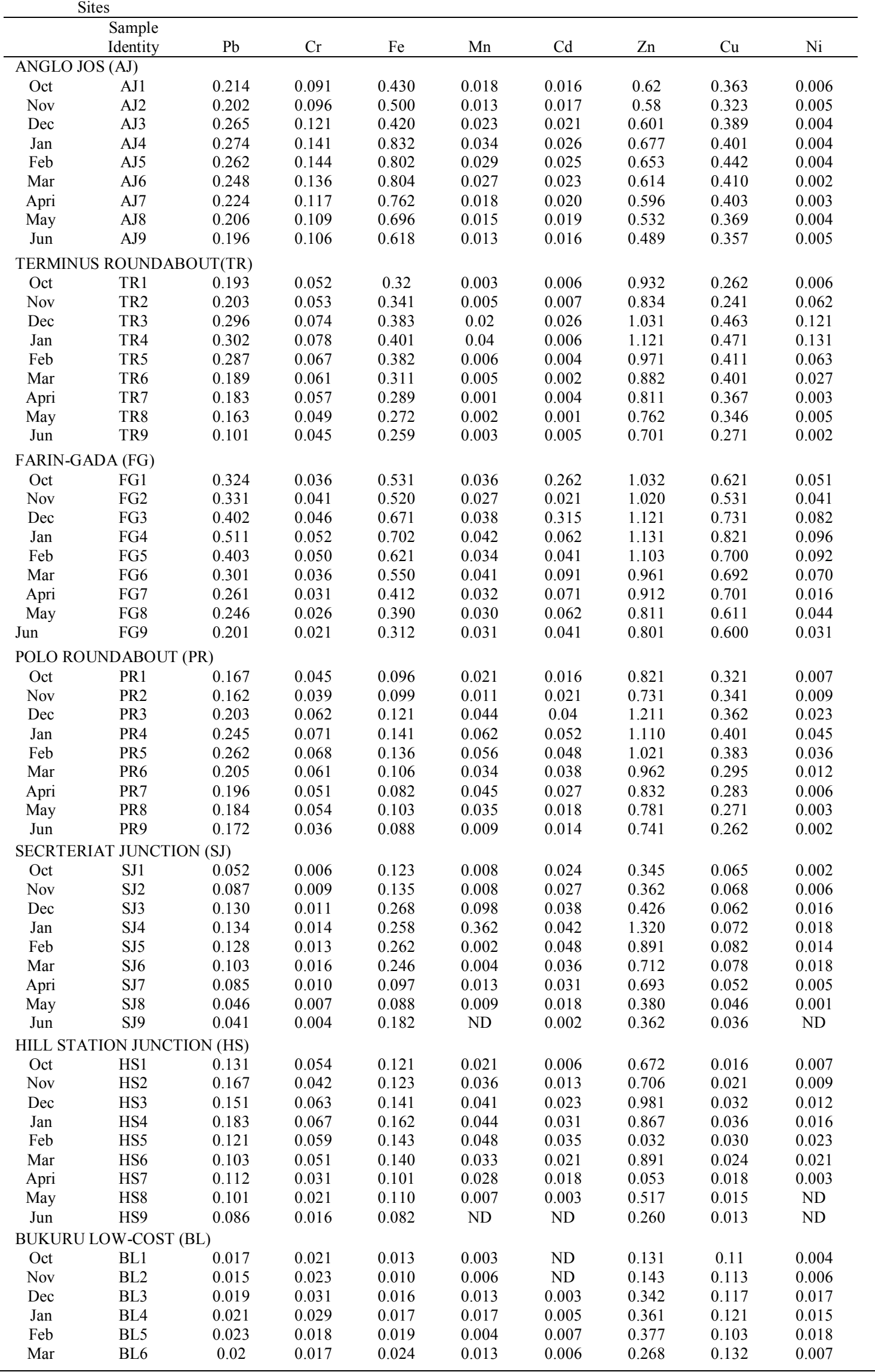


Monitoring and Statistical Evaluation of Heavy Metals in Respirable Dust in Jos Metropolitan Area,

$\begin{array}{llllllllll}\text { Apri } & \text { BL7 } & 0.013 & 0.003 & 0.006 & 0.006 & \text { ND } & 0.211 & 0.092 & \text { ND } \\ \text { May } & \text { BL8 } & 0.011 & \text { ND } & 0.001 & \text { ND } & \text { ND } & 0.162 & 0.087 & \text { ND } \\ \text { Jun } & \text { BL9 } & 0.004 & \text { ND } & \text { ND } & \text { ND } & \text { ND } & 0.103 & 0.099 & \text { ND }\end{array}$

Nickel is found primarily combined with oxygen or sulphur. Small particles in the air are settled to the ground or taken out of the air in rain. The concentration of Ni determined in all the sites ranged from $0.004-0.058 \mathrm{mg} / \mathrm{kg}$. The concentration of Nickel at Bukuru Low Cost Estate (control site) was not detected perhaps due to very low concentration beyond the detection limit as shown in Table 3. The observed concentration of Nickel in other sampling sites may be as a result of anthropogenic sources of Nickel emission to atmosphere through combination of fuel and residual oil burning, mining, and municipal waste incineration. Also local sources as heating, heavy traffic and industry in a particular area are most likely sources. Other sources of exposure are tobacco smoke, auto exhaust, fertilizers, food processing, hydrogenated-fats-oils and industrial waste. The most common adverse health effect of Nickel in human is an allergic reaction such skin rash. Cancers of the lungs and nasal sinus have resulted when workers breathed dust containing high levels of Nickel compounds while working in nickel processing plants (Lazor, et al., 2012)

In nature, Chromium element is part of ores mainly as chromites $\left(\mathrm{FeClO}_{4}\right)$ and cryolite $\left(\mathrm{PbCrO}_{4}\right)$ and is essential for the insulin molecule to bring glucose into the cells for glycolysis. The Chromium particles in air settle in less than ten (10) days and sticks strongly to soil particles. In water it sticks to dirt particles that fall to the bottom and only a small amount dissolves. The concentration of Chromium determined in respirable dust in all the sites ranged from 0.016 $0.118 \mathrm{mg} / \mathrm{kg}$ during the period of assessment. The highest mean value was obtained in Anglo Jos (AJ) $0.054 \mathrm{mg} / \mathrm{kg}$, while the least value was obtained at Secretariat junction (SJ) $0,010 \mathrm{mg} / \mathrm{kg}$ as depicted in Table 4. Heavy metal pollution of air can arise from many sources, but $\mathrm{Cr}$ arises commonly from fossil fuel burning, preparation of nuclear fuels, electroplating such as chromesteel or chrome-nickel (stainless steel) and other alloys, brick in furnaces, and dye and pigment (Melaku, et al., 2008 and Lazor, et al., 2012). All forms of Chromium can be toxic at high levels but $\mathrm{Cr}^{6+}$ is more toxic than $\mathrm{Cr}^{3+}$ in air and can damage and irritate the nose, lungs, stomach and intestines. Skin contact with solids containing $\mathrm{Cr}^{6+}$ may lead to ulcers (Peters, et al., 2001).

Although, Copper is an essential element to human life, high doses can cause anaemia, liver and kidney damage, stomach and intestinal irritation. The concentration of Copper determined in all the sampling sites ranged from $0.023-0.0668 \mathrm{mg} / \mathrm{kg}$, with the highest mean value obtained at Farin Gada (FG) $0.668 \mathrm{mg} / \mathrm{kg}$ and least value obtained at Hill Station Junction (SJ) $0.023 \mathrm{mg} / \mathrm{kg}$. Table 4. The consistent occurrences of Copper implies that the particulates originate from weathering of a unique from of a geological material due to wind erosion, construction work, traffic related and residential activities.

The concentration of Iron determined in all the sites ranges from $0.012-0.652 \mathrm{mg} / \mathrm{kg}$. The highest concentration of Iron was obtained at Anglo Jos (AJ), $0.652 \mathrm{mg} / \mathrm{kg}$ while the least value was obtained at Bukuru low-cost (BL) $0.012 \mathrm{mg} / \mathrm{kg}$ (Table 4). Generally, concentration of Iron was ranked second highest after Zinc concentration in the respirable dust across the sampling sites. The consistent high occurrence of Iron imply that particulates originate from weathering of a unique form of local geological materials due to wind erosion, construction work, traffic related and residential activities.

Zinc is one of the commonest elements in the earth's crust and is found in air, water, and almost all foods. It attaches to dust particles in the air and normally removes by rain into the soil and water. Zinc is an essential element in our diet, insufficient amount of it can cause health problems and too much of it is also harmful. The concentration of Zinc determined in all the sites ranges from $0.233-988 \mathrm{mg} / \mathrm{kg}$. Similarly, the highest concentration was obtained in Farin Gada (FG) $0.988 \mathrm{mg} / \mathrm{kg}$, while the least value was obtained at Secretariat Junction (SJ) $0.548 \mathrm{mg} / \mathrm{kg}$ presented in Table 4. The presence of Zinc in the atmosphere could be attributed to wind-blown soil road dust, metallurgical plants and brass/zinc production facilities (Awan and Ahmed, 2011). The consistent occurrences of Zinc imply that the particulates originate from weathering of a unique form of local geological materials due to wind erosion, construction work, traffic related and residential activities. Breathing large amount of Zinc as dust or fumes can cause specific short-term disease called metal fume fever. This is believed to be an immune response affecting the lungs and body temperature (Underwood, 1971). 
Table 4: Mean concentrations of the heavy metals in respirable dust $(\mathrm{mg} / \mathrm{kg})$ in the study site

\begin{tabular}{|c|c|c|c|c|c|c|c|c|}
\hline Location & $\mathrm{Pb}$ & $\mathrm{Cr}$ & $\mathrm{Fe}$ & $\mathrm{Mn}$ & $\mathrm{Cd}$ & $\mathrm{Zn}$ & $\mathrm{Cu}$ & $\mathrm{Ni}$ \\
\hline Anglo Jos & 0.232 & 0.118 & 0.652 & 0.021 & 0.020 & 0.596 & 0.384 & 0.004 \\
\hline Terminus roundabout & 0.213 & 0.060 & 0.329 & 0.009 & 0.007 & 0.894 & 0.359 & 0.047 \\
\hline Farin Gada & 0.320 & 0.038 & 0.523 & 0.035 & 0.107 & 0.988 & 0.668 & 0.058 \\
\hline Polo Roundabout & 0.199 & 0.054 & 0.108 & 0.035 & 0.030 & 0.912 & 0.324 & 0.016 \\
\hline Secretariat Junction & 0.090 & 0.010 & 0.184 & 0.056 & 0.030 & 0.548 & 0.062 & 0.009 \\
\hline Hill Station & 0.128 & 0.045 & 0.125 & 0.029 & 0.017 & 0.615 & 0.023 & 0.010 \\
\hline Bukuru Low-cost & 0.016 & 0.016 & 0.012 & 0.007 & 0.002 & 0.233 & 0.108 & ND \\
\hline
\end{tabular}

\section{Testing the significance of differences between several mean concentrations of different locations}

Statistical evaluation using one-way analysis of variance (ANOVA) was carried out to correlate the significant differences for the investigated metals between the different chosen locations during the period of October 2013 to June 2014. Sources of variance between different locations for each of the investigated elements was calculated base on the sum of squares between different sites (Bet ss), sum of squares within the different sites(with ss) and the total sum of squares (total ss). Difference F, values for the investigated metal are given in Table 5. The highest $\mathrm{F}$ value was obtained for copper while the lowest was obtained for manganese.

The output of the analysis in Table 6 . below clearly revealed that differences exist significantly in the mean value for all the elements across the study sites with the exception of Mn which alone mean value was seen not to be significantly different across the study sites. The $\mathrm{p}$-values for the seven elements were seen to be about (0.0001) much less than the level of significant (0.05) while for Mn which alone the p-value is ( 0.318$)$ greater than the level of significant (0.05). This means there is significant difference in the mean values of the elements such as $\mathrm{Pb}, \mathrm{Cr}, \mathrm{fe}, \mathrm{Cd}, \mathrm{Zn}, \mathrm{Cu}$ and $\mathrm{Ni}$ across the study areas while there was no significant difference in the mean values of $\mathrm{Mn}$ across the study areas. This indicate that all the metals are highly dependent on sites except manganese.

Table 5: Analysis of Variance (ANOVA) for the different heavy metals at different locations

\begin{tabular}{|c|c|c|c|c|c|c|c|}
\hline Source of varia & & DF & SS & Ms & $\mathrm{F}$ & $\mathrm{P}$ & \\
\hline $\mathrm{Pb}$ & Bet & ss 6 & & 0.549 & 0.092 & 42.982 & 0.0001 \\
\hline & with & ss 56 & & 0.119 & 0.002 & & \\
\hline & total & 62 & & 0.669 & & & \\
\hline $\mathrm{Cr}$ & Bet & ss 6 & & 0.069 & 0.011 & 63.186 & 0.0001 \\
\hline & with & ss 56 & & 0.010 & 0.000 & & \\
\hline & total & 63 & & 0.079 & & & \\
\hline $\mathrm{Fe}$ & Bet & ss 6 & & 3.008 & 0.501 & 64.749 & 0.0001 \\
\hline & with & ss 56 & & 0.434 & 0.008 & & \\
\hline & total & 62 & & 3.442 & & & \\
\hline $\mathrm{Mn}$ & Bet & ss 6 & & 0.015 & 0.003 & 1.200 & 0.3180 \\
\hline & with & ss 56 & & 0.120 & 0.002 & & \\
\hline & total & 62 & & 0.136 & & & \\
\hline $\mathrm{Cd}$ & Bet & ss 6 & & 0.068 & 0.011 & 6.750 & 0.0001 \\
\hline & with & ss 56 & & 0.094 & 0.002 & & \\
\hline & total & 63 & & 0.162 & & & \\
\hline $\mathrm{Zn}$ & Bet & ss 6 & & 3.805 & 0.634 & 13.974 & 0.001 \\
\hline & with & ss 56 & & 2.541 & 0.045 & & \\
\hline & total & 62 & & 6.346 & & & \\
\hline $\mathrm{Cu}$ & Bet & ss 6 & & 2.810 & 0.468 & 172.251 & 0.0001 \\
\hline & with & ss 56 & & 0.152 & 0.003 & & \\
\hline & total & 62 & & 2.962 & & & \\
\hline $\mathrm{Ni}$ & Bet & ss 6 & & 0.025 & 0.004 & 7.679 & 0.0001 \\
\hline & with & ss 56 & & 0.031 & 0.001 & & \\
\hline & total & 62 & & 0.056 & & & \\
\hline
\end{tabular}




\section{Concentration and Time Dependence.}

Another area that also warrant interest is the measurement of the time dependence of dust emission to identify site exposed during peak emissions. Exposure is a function of time dosage and time, and it possible that exposure to high concentration for even short period can present a serious health hazard.

Base on the mean concentration represented on table 6. It was find that the highest peak emission for the investigation metals were in January for $\mathrm{Pb}, \mathrm{Cr}, \mathrm{Fe}, \mathrm{Zn}, \mathrm{Cu}$, and Ni, and December for $\mathrm{Cd}$ this could be as a result high peak period of hammatan in Jos accompanied dust blown from all directions.

Table 6: Mean concentrations $(\mathrm{mg} / \mathrm{kg}$ ) of the investigated heavy metals at different months

\begin{tabular}{|c|c|c|c|c|c|c|c|c|}
\hline & $\mathrm{Pb}$ & $\mathrm{Cr}$ & $\mathrm{Fe}$ & $\mathrm{Mn}$ & $\mathrm{Cd}$ & $\mathrm{Zn}$ & $\mathrm{Cu}$ & $\mathrm{Ni}$ \\
\hline Oct & 0.157 & 0.044 & 0.233 & 0.016 & 0.047 & 0.650 & 0.251 & 0.012 \\
\hline Nov & 0.167 & 0.043 & 0.250 & 0.015 & 0.015 & 0.636 & 0.234 & 0.020 \\
\hline Dec & 0.209 & 0.058 & 0.289 & 0.040 & 0.067 & 0.816 & 0.308 & 0.039 \\
\hline Jan & 0.224 & 0.065 & 0.359 & 0.086 & 0.032 & 0.941 & 0.332 & 0.046 \\
\hline Feb & 0.212 & 0.060 & 0.338 & 0.026 & 0.030 & 0.721 & 0.307 & 0.036 \\
\hline Mar & 0.167 & 0.054 & 0.312 & 0.022 & 0.031 & 0.756 & 0.290 & 0.022 \\
\hline Apri & 0.153 & 0.043 & 0.250 & 0.020 & 0.024 & 0.587 & 0.274 & 0.005 \\
\hline May & 0.137 & 0.038 & 0.237 & 0.014 & 0.017 & 0.564 & 0.249 & 0.008 \\
\hline Jun & 0.114 & 0.033 & 0.220 & 0.008 & 0.011 & 0.011 & 0.234 & 0.006 \\
\hline
\end{tabular}

The lowest peak emissions for the investigated metals were in $\mathrm{June}$ for $\mathrm{Pb}, \mathrm{Cr}, \mathrm{Fe}, \mathrm{Cd}$, and $\mathrm{Zn}$, April for Mn, and Ni. This could be associated with rainfall during the period that might have wash off dust from air and the roads. Most of the metals reached their maximum concentration at January and December. This is consistent with the increased activities leading to particulate matter emission during the harmmatan period.

To correlate the significant differences for the investigated heavy metals during the period starting from October 2013 to June 2014, ANOVA was used and the results are given in Table 7. Despite the fact that the data demonstrated high mean value in December, January and February, the statistical analyses of the data revealed that the metals depends on the months during the investigated period. This variation could be due to seasonal changes within the months.

Table 7: Analysis of Variance (ANOVA) for the different heavy metals at different months

\begin{tabular}{|c|c|c|c|c|c|c|c|}
\hline \multicolumn{3}{|c|}{ Source of variation } & Df & SS & MS & $\mathrm{F}$ & $P$ \\
\hline \multirow[t]{2}{*}{$\mathrm{Pb}$} & Bet & ss & 8 & 0.077 & 0.010 & 0.873 & 0.545 \\
\hline & $\begin{array}{l}\text { with } \\
\text { total }\end{array}$ & ss & $\begin{array}{l}54 \\
62\end{array}$ & $\begin{array}{l}0.592 \\
0.669\end{array}$ & 0.011 & & \\
\hline \multirow[t]{3}{*}{$\mathrm{Cr}$} & Bet & ss & 8 & 0.007 & 0.001 & 0.574 & 0.751 \\
\hline & with & ss & 54 & 0.072 & 0.001 & & \\
\hline & total & & 62 & 0.079 & & & \\
\hline \multirow[t]{3}{*}{$\mathrm{Fe}$} & Bet & ss & 8 & 0.141 & 0.018 & 0.288 & 0.967 \\
\hline & with & ss & 54 & 3.301 & 0.061 & & \\
\hline & total & & 62 & 3.442 & & & \\
\hline \multirow[t]{3}{*}{$\mathrm{Mn}$} & Bet & ss & 8 & 0.031 & 0.004 & 2.035 & 0.059 \\
\hline & with & ss & 54 & 0.104 & 0.002 & & \\
\hline & total & & 62 & 0.136 & & & \\
\hline \multirow[t]{3}{*}{$\mathrm{Cd}$} & Bet & ss & 8 & 0.017 & 0.002 & 0.782 & 0.620 \\
\hline & with & ss & 54 & 0.145 & 0.003 & & \\
\hline & total & & 62 & 0.162 & & & \\
\hline \multirow[t]{3}{*}{$\mathrm{Zn}$} & Bet & ss & 8 & 3.816 & 0.477 & 1.388 & 0.000 \\
\hline & with & ss & 54 & 4.842 & 0.090 & & \\
\hline & total & & 62 & 8.658 & & & \\
\hline \multirow[t]{3}{*}{$\mathrm{Cu}$} & Bet & ss & 8 & 0.071 & 0.009 & 0.167 & 0.994 \\
\hline & with & ss & 54 & 2.891 & 0.054 & & \\
\hline & total & & 62 & 2.962 & & & \\
\hline \multirow[t]{3}{*}{$\mathrm{Ni}$} & Bet & ss & 8 & 0.014 & 0.002 & 2.164 & 0.045 \\
\hline & with & ss & 54 & 0.042 & 0.001 & & \\
\hline & total & & 62 & 0.056 & & & \\
\hline
\end{tabular}




\section{Safety Levels}

The WHO air quality guideline (WHO,1997) state that different effects on mortality, respiratory and cardiovascular hospital admission has been observed at daily average $\mathrm{PM}<10 \mu \mathrm{g} / \mathrm{m}^{3}$ levels well below $100 \mu \mathrm{g} / \mathrm{m}^{3}$. In Western Europe, North America and Western pacific except China annual $\mathrm{PM}<10 \mu \mathrm{g} / \mathrm{m}^{3}$ concentration range between 10 and $55 \mu \mathrm{g} / \mathrm{m}^{3}$. High $\mathrm{PM}<10 \mu \mathrm{g} / \mathrm{m}^{3}$ annual mean concentration are found in South East Asia ranging between 100 and $400 \mu \mathrm{g} / \mathrm{m}^{3}$. However, the highest concentration were recorded in larger cities.

In Jos, Nigeria it was found that the obtained mean during the period of assessment $\mathrm{PM}<10 \mu \mathrm{g} / \mathrm{m}^{3}$ ranges from 111 and $192 \mu \mathrm{g} / \mathrm{m}^{3}$ at Anglo Jos, 125 and $179 \mu \mathrm{g} / \mathrm{m}^{3}$ in Terminus roundabout, 136 and $256 \mu \mathrm{g} / \mathrm{m}^{3}$ at Farin Gada, 82, and 175 $\mu \mathrm{g} / \mathrm{m}^{3}$ in Polo Roundabout, 137 and $308 \mu \mathrm{g} / \mathrm{m}^{3}$ in Secretarial Junction, 77 and $143 \mu \mathrm{g} / \mathrm{m}^{3}$ in Hill Station Junction and 42 and $89 \mu \mathrm{g} / \mathrm{m}^{3}$ in Bukuru Low-Cost Estate. These figures demonstrate obtained Jos are low compared to values recorded in Cairo Egypt and China East Asia.

According to the WHO the annual Pb mean lead concentration is Ambient Air is below 0.1 Europe and between 0.2 and $0.6 \mathrm{mg} / \mathrm{kg}$ in Eastern European cities. In North American cities, annual mean Pb concentration is below $0.05 \mathrm{mg} / \mathrm{kg}$. In the studied site Jos, Nigeria, the mean concentration of lead was observed to be $0.016-0.331 \mathrm{mg} / \mathrm{kg}$.

The values reported for $\mathrm{Pb}$ in this research are lower compared to the literature values obtained in Eastern European cities.

However, there was no annual limit for $\mathrm{Cd}, \mathrm{Zn}$, and $\mathrm{Ni}$ in ambient air either in the WHO or Nigerian guideline. The values obtained are considered to be high considering the catalytic nature and toxicity of these metals which upon inhalation may lead to dangerous effects on health. This may be considered a motivation to the international community to define limits for these heavy metals in ambient air

\section{Conclusion}

Generally, the study confirmed that air burden shows a definite mass dependence related to chemical composition of the respirable dust of the air which reflects anthropogenic activities. The concentration of heavy metals in other sites was generally low, the cumulative effect may be significant considering the presence of heavy metals in the environment. The data obtained for the study demonstrated that the distribution of metal concentration in the study sites has come about as a result of anthropogenic influences and vehicular emissions.

\section{Acknowledgements}

We would like to thank the University of Jos, Nigeria for the financial support for this research. Also my appreciation goes to Geology Mining Department, University of Jos for allowing us to use their FAAS for heavy metals determination. My deep appreciation goes to my wife Mrs. Victoria Godwin whose contributions cannot be quantify, you are wonderful. To my children, Godwin Godwin Bwehmana, Abigail Uhan Godwin, Amen Aditi Godwin and Tisyoh Godwin and sisters in-law Mary Simon and Evelyn Dan, you are indelible in my mind and I thank you for your prayers.

\section{References}

[1]. Ahmed, F. and Ishiga, H. (2006) Trace Metals Concentration in Street Dusts of Dhaka City Bangladesh, Atmospheric Environment, 40, 3835-3844.

[2]. Awan, M.A and Ahmed, S.H. (2011) Determination of Total Suspended Particulate Matter and Heavy Metals in Ambient Air of Four Cities of Pakistan. Ironical journal of Energy \& environment, 2. 128-132.

[3]. Aybek, A.and Selcuk, A. (2007) Dust Exposures in Tractor and Combine Operations in Eastern Mediterranean, Turkey. Journal of Environmental Biology, 28, 717-722.

[4]. Bhargava, A., Gupta, K., Bhargawa, R. and Pardhi, S. (2003) The effects Automobile Exhaust on Total N. P and Heavy Metals of Road Side Sugarcane at District, Saharanpur Ad Plant Science, 16, 557-560.

[5]. Curtis, L. W., Pea, P. Smith-Willis, E, Fenyves and Y. Pan (2006): Adverse Health Effects of Outdoor Air Pollutants. Environ.Intern.32, 815-830.

[6]. Garcia, R. B., Padilla,H., Tores, M. C and Baez ,A. (2009): Trace metal and inorganic ions Measurement in Rain from mexico and nearby rural area. Revised chemistry and ecology 25(2) Pp.71-86.

[7]. Gbadebo, A.M. and Bankole, O.D. (2007) Analysis of Potentially Toxic Metals in Airborne Cement Dust around Sagamu South Western Nigeria. Journal of Applied Sciences, 7, 35-40.

[8]. Kim, K., Lee, J. and Jang, M.(2002) Metals in Airborne Particulate Matter from the First and Second Industrial Complex Area of Taejon City, Korea. Environmental Pollution, 118, 41-51.

[9]. Lazor, P., Tomas, J.,Toth, J. and Ceryova, S. (2012) Monitoring of Air Pollution and Atmospheric Deposition of Heavy Metals by Analysis of Honey. Journal of Microbiology, Biotechnology and Food Sciences, 1, 522-535.

[10]. Lopez, J.M., Callen, M>S>, Murillo, R., Garcia, T., Navarro,. M.V.,dela Cruz, M.T., and Mastral, A.m., (2005) Levels of Selected Metals in Ambient Air PM10 in an Urban Site of Zaragoza, Spain Environmental Research, 99, 58-67.

[11]. Melaku, S., Morris, V., Raghavan, D. and Hosten, C. (2008) Seasonal Variation of Heavy Metals in Ambient Air and Precipitation at a Single Site in Washington, DC. Environmental Pollution, 155, 88-98.

[12]. National Environmental Protection Council (NEPC), 2002. Ambient air quality standards. http://www.environment.gov.au/atmosphere/airquality/standards.html

[13]. Peters, A., Dockery, D.W., Millerm J.F. and Mittelman, M.A. (2001) Increase Particulate Matter and the Triggering Myocardial Infarction. Circulation, 103,2810-2815.

[14]. Pope, C.A., Bates, D.A. and Raizenne, M.E. (1995) ‘Article Title’ Environmental Health Perspective, 103, $472-479$.

[15]. Ran, M.N. and Rao, H.V.N. (1989) Air Pollution, Data McGraw-Hill Publishing Company Ltd., New Delhi, 10-25. 
[16]. Sezgin, N., Ozean, H.K. , Demir, G., Nemlioglu, S. and Bayet, C. (2006) Determination of Heavy Metals in Street Dust in Istanbul Highway. Environmental International, 29, 797- 985.

[17]. Shah, J. Nagpa. J. T. and Bmadon, C. (2006) Urban air Quality Management Strategy in Asia-Guide Book. The World Bank, USA. $17-21$

[18]. Shinggu, D.Y., Ogugbuaja, V., Toma, O. And Barminas, J.T.(2010) Determination of Heavy Metals in Street Dust in Yola, Nigeria. African journal of pure and Applied Chemistry, 4. 17 - 20.

[19]. Sombo, T. (2006) Thesis Particulate Matter Sampling and Characterization. M.Sc. Unpublished Thesis, University of Agriculture, Markurdi.

[20]. Stone, E.A., Yoon, S.C. and Schauer, J.J. (2011) Chemical Characterization of fine and Coarse Particles in Gosan, Korea during Springtime Dust Events. Aerosol Air Quality Research, 11, 31-43.

[21]. Tsor, O.J. (2003) The characterization of Atmospheric Aerosol during Harmattan in Three Nigerian Cities. M.Sc. Thesis, University of Jos, Jos

[22]. Underwood, E. J. (1971): Trace Elements in Human and Animal Nutrition, Academic Press, New York.

[23]. U.S.EPA (2012): Air Quality Criteria for Particulate Matter Vol. 1-3 Office of Research and Development Washington DC. (EPA Report No.EPA/001a-c).

[24]. Vandana Tyagi B.R., Gurjar,N. Joshi and P. Kumar (2011): PM10 and Heavy Metals in Suburban and Rural Atmospheric Environments of Northern India. Dept.of Civil Engineering, Indian Institute of Technology Roorkee, Roorkee 247667, India.

[25]. WHO Guidelines for Air Quality, Facts sheet No. 187, World Health Organisation Geneva, (1997).

[26]. USAID/Egypt,(1994) in: Comparing Environmental Health Risks in Cairo, Egypt, vol.2: Technical Annexes pp.A6-7.

[27]. Zhao, J., Zhang, F., Xu, Y., Chen, J., Yin, L., Shang, X. and Xu, L. (2011) Chemical Characterizations of Particulate Matter during a Heavy Dust Episode in a Coastal City, Xiamen. Aerosol Air Quality Research, 11, 299-308. 